\title{
衝撃試験における上部降伏点の測定誤差*
}

\author{
川西 哲夫**.酒 井 拓**.作井 誠太***
}

\section{Error in Measurement of Upper Yield Stress in Impact Test}

\section{Tetsuo Kawanishi, Taku Sakai, and Seita Sakui}

金属の衝整試験における測定精度は第1にロードセ ル, 動歪計, 記録計器などの测定系の動的特性により, 第 2 に応力波伝播の問題によつて決ます. 本報告は第 2 の問題を考虑する必要のない条件下で, 鉄鋼の上部降伏 点の測定精度が第1の問題によつてどのように影響され るかを検討したものである。

一般のロードセルによる応力測定系は棒の縦振動とし て取报うのが正しいが，ここでは振動の高次モードを無 視し，1自由度系で近似して解析した1). 外力 $f(t)$ を Fig. 1(b)の実線のごとく与えた場合の Fig. 1（a）の ような1自由度振動系の運動方程式は, 時間領域によつ て次の 2 つの式にわけられる.

$$
m \cdot \ddot{x}+c \cdot \dot{x}+k \cdot x=\frac{f_{0}}{t_{\mathrm{r}}} \cdot t \quad\left(0<t \leqq t_{\mathrm{r}}\right)
$$

$$
m \cdot \ddot{x}+c \cdot \dot{x}+k \cdot x=f_{0}(1-X) \quad\left(t_{\mathrm{r}}<t\right) \cdots \cdots(\mathrm{I} \mathrm{b})
$$
ここで $m, c, k$ はロードセルと試験片取付具を含めた 系の等価質量, 等価減衰係数, 等価ばね定数である. $x$ は変位を表わし $f_{0}, t_{\mathrm{r}}$ は Fig. 1（b）の実線で示す外 力の最大值と立上り時間である. $X$ は上部, 下部両降伏 点の差と上部降伏点との比である. このときのロードセ ルの出力波形に相当するバネの両端に㗢く力 $f$ は, Fig. l(b) の破線のように応答する. この破線の最大值 $f_{\mathrm{m}}$ と入力の最大值 $f_{0}$ との差を $f_{0}$ で割つた值が求めるオ ーバーシュートである. 途中の計算はすべて省略して式 (1)の解を $f / f_{0}$ の形で示す.

\footnotetext{
* 昭和 46 年11月17日受付

** 電気通信大学

*** 電気通信大学 工博
}

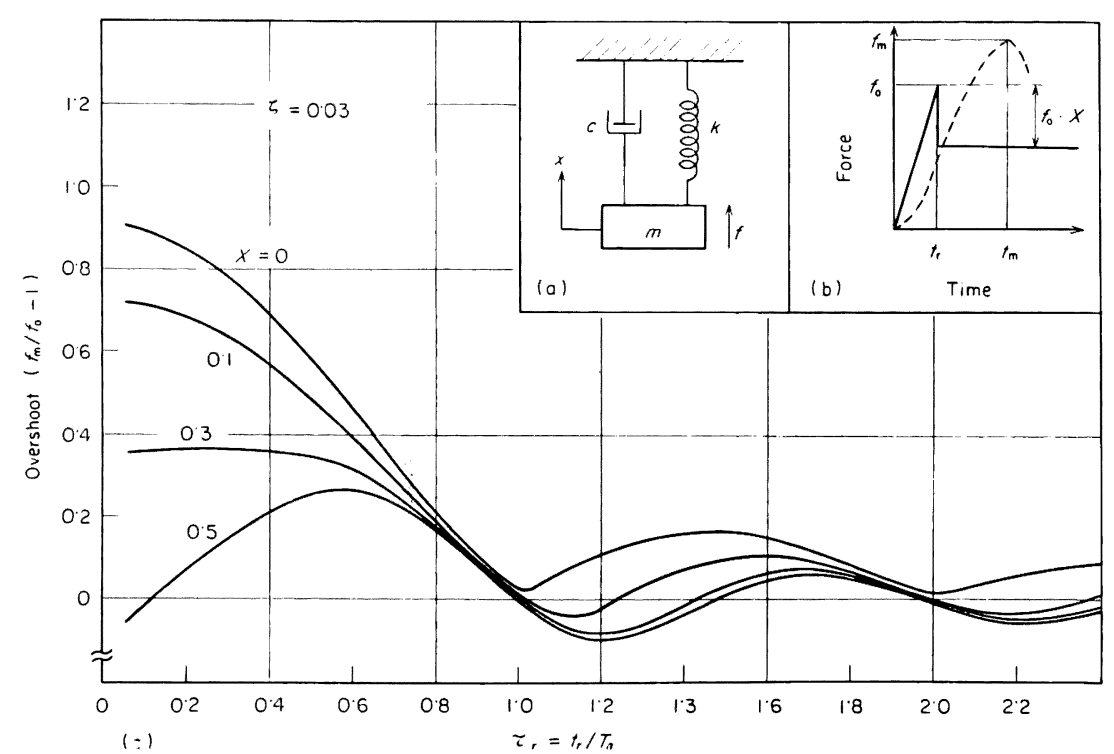

Fig. 1. (a ) Diagram of vibrating system with a single degree of freedom.

(b) Force-Time curves. A solid line is a input force signal and a broken line is its response.

(c) The change of overshoot parameter $\left(f_{\mathrm{m}} / f_{0}\right)$ with $\tau_{\mathrm{r}}=t_{\mathrm{r}} / T_{\mathrm{n}}$ and $X$. 


$$
\begin{aligned}
& \frac{f}{f_{0}}=x_{0}\left[\frac{1}{q} \cdot e^{-2 \pi \zeta \tau} \cdot \cos (2 \pi q \tau+\alpha)\right] \\
& +\left(v_{0}+2 \zeta x_{0}\right)\left[\frac{1}{q} \cdot e^{-2 \pi \zeta \tau} \cdot \sin 2 \pi q \tau\right] \\
& +(1-X)\left[1-\frac{1}{q} \cdot e^{-2 \pi \zeta \tau} \cdot \cos (2 \pi q \tau-\alpha)\right], \\
& \left(t_{\mathrm{r}}<t\right) \\
& x_{0}=\left(1-\frac{\zeta}{2 \tau_{\mathrm{r}}}\right)-\frac{e^{-2 \pi \zeta \tau_{\mathrm{r}}}}{2 \pi q \tau_{\mathrm{r}}}\left[\sin 2 \pi q \tau_{\mathrm{r}}\right. \\
& \left.-2 \cdot \zeta \cdot \cos \left(2 \pi q \tau_{\mathrm{r}}-\alpha\right)\right] \\
& \left.\left.+2 \zeta \cdot \sin \left(2 q \tau_{\mathrm{r}} \cdots \alpha\right)\right]\right\}
\end{aligned}
$$

ここで

$\zeta=c / 2 \sqrt{m k}, q=\sqrt{1-\zeta^{2}}, \alpha=\tan ^{-1}\left(\zeta / \sqrt{1-\zeta^{2}}\right)$, $\tau=t / T_{\mathrm{n}}, \quad \tau_{\mathrm{r}}=t_{\mathrm{r}} / T_{\mathrm{n}}, \quad T_{\mathrm{n}}=2 \pi / w_{\mathrm{n}}, \quad w_{\mathrm{n}}=\sqrt{k / m}$

であり, 便宜上式 (2), (3)のすべての量は無次元量と してある.これょりロードセルを構成する応力測定系の 减衰保数比 $\zeta$, 固有振動数 $w_{\mathrm{n}}$ ならびに $t_{\mathrm{r}}$ と $X$ で示 される外力の形状を知れば，オーバーシュートを計算で
求めることができる、計算結果の主要点は次のようにま

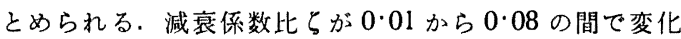
してもオーバーシュートにはあまり影惫しない. Fig. 1 (c) は $\zeta=0.03$ と一定にしたときの $f_{\mathrm{m}} / f_{0}$ か $t_{\mathrm{r}} / T_{\mathrm{n}}=$ テrとXとによつてどのように変化するかを示している． $f_{\mathrm{m}} / f_{0}$ はおよそ $\tau_{\mathrm{r}}=1$ を周期として変化している. 衝 棨試験では立上り時間 $t_{\mathrm{r}}$ が非常に小さくなるが，一方 ロードセルを構成する応力測定采の $w_{\mathrm{n}}$ は限定されるた め大体 $\tau_{\mathrm{r}}$ が 2 以下となる。したがつて衝慗試験では才 一パーシュートがかなり大きく，その大きさは $\tau_{\mathrm{r}}$ と $X$ によつて大きく变化することがわかる．実際の実験条件 に近いたとえば $\zeta=0.03 ， \tau_{\mathrm{r}}=0.6$ (実駼装置と変形速度 によつて決定される.) の場合の $f_{\mathrm{m}} / f_{0}$ の值は，X $X$ 0.1 から 0.3 の間で変化すると仮定しても 1.39 から 1.30 の間で変化する. すなわち経䓉的に知られている $X$ の変化の籁囲内では，上記の装置による応力の測定誤 差はだいたい 35\% 程度となり，これだけの補正をして やれば真の上部降代点がほほ $\pm 5 \%$ の誤差で求めるこ とができる。

\section{交献}

1) C. H. Chiang: J. Inst. Metals, 98 (1970), p.78 